\title{
LOWER EXTREMITY ARTERY DISEASE AS A PREDICTOR OF CORONARY ARTERY DISEASE
}

\author{
CORNEL IOAN BITEA ${ }^{1}$, IOAN MANIȚIU ${ }^{2}$, GEORGIANA BĂLȚAT $^{3}$ \\ ${ }^{1,3}$ Emergency County Clinical Hospital, Sibiu, ${ }^{1,2,3}$ "Lucian Blaga” University of Sibiu, \\ ${ }^{1,3}$ Invasive and non-invasive research centre in the field of cardiac and vascular pathology in adults - CVASIC, Sibiu
}

\begin{abstract}
Keywords: $\quad$ lower Abstract: Coronary artery disease (CAD) is an important determinant of long-term outcome in extremity artery disease, patients with lower extremity artery disease (LEAD). In this study we evaluated the CAD prevalence coronary artery disease, among LEAD patients and the association of LEAD lesions location with the CAD presence and predictor severity. 203 patients with LEAD, referred for peripheral and simultaneous coronary angiography, were evaluated. $L E A D$ and CAD were considered angiographically significant for stenosis higher than $50 \%$ of arterial lumen. More than two-thirds of LEAD patients had significant CAD, half of them having multi-vessel CAD and a quarter single CAD. Infrapoplitheal arterial lesions seemed to be the strongest predictor of CAD being associated with significant and multi-vessel CAD and also with the presence of left main (LM) lesions. Femoral artery lesions were highly associated with multi-vessel $C A D$, but there was no association with significant CAD and LM lesions. No association was found between iliac artery lesions and CAD.
\end{abstract}

\section{INTRODUCTION}

Atherosclerosis is the main cause of lower extremity artery disease (LEAD) and coronary artery disease (CAD). Previous studies have shown that peripheral artery disease, which includes LEAD, is a CAD risk equivalent. $(1,2)$

High prevalence of CAD in peripheral artery disease patients was noted, ranging from 46 to $71 \% .(3,4,5)$ LEAD is highly associated with CAD, one-third of patients having a history and/or electrocardiographic signs of CAD, two-thirds presents changes in stress tests and up to $70 \%$ have at least single-CAD. $(6,7,8)$ Studies have shown that patients with stable atherosclerotic disease, but without previous ischemic events, have more cardiovascular events in context of multi-arterial disease.(9) Moreover, mortality and long term prognosis in LEAD patients is directly correlated with CAD coexistence. $(5,10,11,12)$ Not only the presence, but also the LEAD severity is correlated with CAD association: a high percentage of patients (up to 90\%) that present in medical units with chronic limb-threatening ischemia also have CAD.(6)

The predictive value of LEAD lesion location for CAD was evaluated in several studies. Sung Woo et al demonstrated that the prevalence of proximal disease, defined as aortic-iliac and femoral-popliteal arteries stenosis, was higher in the normal or single CAD group, whereas that of involvement of both levels (proximal and distal, the last one being defined as below knee arteries) was higher in the multivessel CAD group.(5)

Multisystemic involvement of vascular disease is demonstrated in day by day practice. Association of CAD with peripheral artery disease, including LEAD, is clinically important, being well known that outcome of LEAD patients is influenced by the presence and severity of CAD. In this context, Current European guideline for peripheral artery disease (2017) recommends CAD screening in LEAD patients for risk stratification.(6)

\section{AIM}

The aim of this study was to see if there is any association between significant LEAD and CAD, if higher than $50 \%$ arterial stenosis in different segments of lower extremity arterial bed correlates with significant vs non-significant CAD, with single- vs multivessel-CAD and with left main lesions.

\section{MATERIALS AND METHODS}

We retrospectively reviewed 203 patients with symptomatic LEAD (intermittent claudication or critical limb ischemia) which underwent simultaneously digital subtraction angiography for LEAD evaluation and coronary angiography for CAD evaluation in Sibiu Emergency County Clinical Hospital, CVASIC research centre. There were excluded patients with embolic or non-atherosclerotic lower extremity artery lesions, being included only patients with chronic atherosclerotic lesions.

Significant LEAD and CAD were defined as at least one lesion with $\geq 50 \%$ lumen diameter stenosis. Lower extremity arteries were divided into three segments: iliac (common iliac artery, external iliac artery, internal iliac artery), femoral (common and superficial femoral artery and popliteal artery) and infrapopliteal (tibioperonier trunk, anterior tibial artery, posterior tibial artery, fibular artery). CAD was classified as significant-CAD (any coronary artery stenosis $\geq 50 \%$ lumen diameter in left main (LM) artery or left anterior descending (LAD) artery or circumflex artery (CxA) or right coronary artery (RCA)) or non-significant-CAD (without coronary artery stenosis $\geq 50 \%$ lumen) and as single-CAD (only one of LAD or CxA or RCA with lesion above 50\%) or multivessel-CAD (LM stenosis $\geq 50 \%$, or any of two arteries from LAD, CxA, RCA with arterial stenosis $\geq 50 \%$ )

\footnotetext{
${ }^{1}$ Corresponding author: Cornel Ioan Bitea, B-dul. Corneliu Coposu, Nr. 2-4, Sibiu, România, E-mail: cornelioanbitea@yahoo.com, Phone: +40766 210522

Article received on 18.02.2021 and accepted for publication on 02.03.2021
} 


\section{CLINICAL ASPECTS}

Cardiovascular risk factors - hypertension, dyslipidaemia and diabetes mellitus - were defined according to current guidelines. The patients were considered positive for smoking if they were active smokers or former smokers - but not more than 1 year abstinence. Normal values for $\mathrm{C}$ reactiveprotein in our laboratory were $0-5 \mathrm{mg} / \mathrm{dl}$. Chronic kidney disease was classified form grade I to $\mathrm{V}$ according to KDOQI classification, and creatinine clearance was calculated with Cockcroft-Gault formula.

Statistical analysis was performed using IBM SPSS Statistic software. Categorical variables are expressed as the number (percentages) and continuous variables were first analysed for data normality. The Shapiro-Willk test was used to analyse data normality. Normally distributed continuous variables were expressed as the mean $\pm \mathrm{SD}$, and non-normally distributed continuous variables were expressed as the median value. Pearson Chi-Square tests was used to evaluate LEAD association with CAD. As a measure of association, we used the gamma- $\gamma$ coefficient (Kendall's tau-c). Statistical significance was considered at a $\mathrm{P}$ value $<0.05$ (two-tailed).

\section{RESULTS}

\section{Patient's characteristics}

Of the 203 patients with symptomatic LEAD, 166 $(81.8 \%)$ were male, $37(18.2 \%)$ were female; the mean age was $65.31 \pm 8.616$ (range 39-85years). Hypertension had the higher prevalence in our study group (79.8\%) followed by smoking (76.84\%), CKD (581\%), hypercholesterolemia (54.7\%), hypertriglyceridemia $(48.3 \%)$ and diabetes mellitus (34.5\%). The majority of patients were with stage II Leriche-Fontaine LEAD - 135 (64.5\%) patients in stage II Leriche-Fontaine, 40 $(19.7 \%)$ in stage III Leriche-Fontaine, $28(13.8 \%)$ in stage IV Leriche Fontaine - with a mean claudication index of $144 \pm 24 \mathrm{~m}$ and a mean ankle-brachial index of $0.62 \pm 0.24$.

Patient's demographic, clinical and biological characteristics are summarised in table no. 1 and table no. 2 .

Table no. 1. Patients' demographic and clinical characteristics

\begin{tabular}{|c|c|c|c|}
\hline Variable $(\mathrm{N}=203)$ & \multicolumn{3}{|c|}{ Value } \\
\hline Age, years & $65.31 \pm 8.6$ & Min: 39 & Max: 85 \\
\hline \multirow[t]{2}{*}{ BMI, $\mathrm{kg} / \mathrm{m}^{2}$} & $27.44 \pm 4.48$ & Min: 17.72 & Max: 43.21 \\
\hline & \multicolumn{2}{|c|}{$\begin{array}{l}\text { Underweight } \\
\text { Normal weight } \\
\text { Overweight } \\
\text { Grade I obesity } \\
\text { Grade II obesity } \\
\text { Grade III obesity }\end{array}$} & $\begin{array}{ll}22 & (1 \%) \\
67 & (33 \%) \\
82 & (40.4 \%) \\
40 & (19.7 \%) \\
10 & (4.9 \%) \\
2 & (1 \%)\end{array}$ \\
\hline Gender & \multicolumn{2}{|l|}{$\begin{array}{l}\text { Male } \\
\text { Female }\end{array}$} & $\begin{array}{l}166(81.8 \%) \\
37(18.2 \%)\end{array}$ \\
\hline Smoking & \multicolumn{2}{|l|}{$\begin{array}{l}\text { Yes } \\
\text { No }\end{array}$} & $\begin{array}{l}156(76.84 \%) \\
47(23.16 \%)\end{array}$ \\
\hline Diabetes mellitus (DM) & \multicolumn{2}{|l|}{$\begin{array}{l}\text { Yes } \\
\text { No }\end{array}$} & $\begin{array}{l}70(34.5 \%) \\
133(65.5 \%) \\
\end{array}$ \\
\hline Hypertension & \multicolumn{2}{|l|}{$\begin{array}{l}\text { Yes } \\
\text { Grade I } \\
\text { Grade II } \\
\text { Grade III } \\
\text { No }\end{array}$} & $\begin{array}{c}162(79.8 \%) \\
0 \quad(0 \%) \\
76(37.4 \%) \\
85(41.9 \%) \\
41(20.2 \%)\end{array}$ \\
\hline Hypercholesterolemia & \multicolumn{2}{|l|}{$\begin{array}{l}\text { Yes } \\
\text { No }\end{array}$} & $\begin{array}{l}11(54.7 \%) \\
92(45.3 \%)\end{array}$ \\
\hline Hypertriglyceridemia & \multicolumn{2}{|l|}{$\begin{array}{l}\text { Yes } \\
\text { No }\end{array}$} & $\begin{array}{l}98(48.3 \%) \\
105(51.7 \%)\end{array}$ \\
\hline CKD & $\begin{array}{c}\text { Yes (Cre } \\
<90 \mathrm{ml} / \mathrm{min} / \\
\text { Grade II } \\
\text { Grade IIIa } \\
\text { IIIb } \\
\text { Grade IV } \\
\text { Grade V } \\
\\
\text { No (Creatin } \\
\mathrm{ml} / \mathrm{min} / 1.73\end{array}$ & $\begin{array}{l}\text { ine clearance } \\
\left.3 \mathrm{~m}^{2}\right)\end{array}$ & $\begin{array}{cc}118(58.1 \%) \\
\\
85(41.9 \%) \\
28(13.8 \%) \\
3 \quad(1.5 \%) \\
2 & (0 \%) \\
3 & (1 \%) \\
& \\
& \\
& (41.9 \%)\end{array}$ \\
\hline
\end{tabular}

\begin{tabular}{|c|c|c|c|}
\hline $\begin{array}{l}\text { Leriche-Fontaine } \\
\text { classification }\end{array}$ & \multicolumn{2}{|c|}{$\begin{array}{l}\text { I : Asymptomatic } \\
\text { IIa: intermittent claudication at } \\
\text { more than } 200 \mathrm{~m} \text { walk } \\
\text { IIb: intermittent claudication } \\
\text { in less than } 200 \mathrm{~m} \text { walk } \\
\text { III: limb rest pain } \\
\text { IV: ischemic lesions - } \\
\text { necrosis, gangrene }\end{array}$} & $\begin{array}{ll}0 & (0 \%) \\
17 & (8.4 \%) \\
118 & (58.1 \%) \\
& \\
40(19.7 \%) \\
28(13.8 \%) \\
\end{array}$ \\
\hline $\begin{array}{l}\text { Claudication index, } m \\
\text { Ankle-Brachial index }\end{array}$ & $\begin{array}{l}144 \pm 24 \\
0.62 \pm 0.24\end{array}$ & $\begin{array}{l}\text { Min: } 0 \\
\text { Min: } 0\end{array}$ & $\begin{array}{l}\text { Max: } 1000 \\
\text { Max: } 1\end{array}$ \\
\hline
\end{tabular}

Table no. 2. Patients' biological characteristics

\begin{tabular}{|l|l|l|l|}
\hline Parameter $(\mathbf{N}=\mathbf{2 0 3})$ & Mean \pm SD & Minimum & Maximum \\
\hline Total cholesterol, $\mathrm{mg} / \mathrm{dl}$ & $207.60 \pm 55.86$ & 107 & 357 \\
\hline LDL-cholesterol, $\mathrm{mg} / \mathrm{dl}$ & $117.57 \pm 43.76$ & 31 & 290 \\
\hline HDL - cholesterol, $\mathrm{mg} / \mathrm{dl}$ & $44.91 \pm 10.93$ & 27 & 86 \\
\hline Triglycerides, $\mathrm{mg} / \mathrm{dl}$ & $185.78 \pm 148.4$ & 44 & 1356 \\
\hline Creatinine, $\mathrm{mg} / \mathrm{dl}$ & $1.02 \pm 0.59$ & 0.55 & 6.88 \\
\hline $\begin{array}{l}\text { Clearance Creatinine, } \\
\mathrm{ml} / \mathrm{min} / 1.73 \mathrm{~m}^{2}\end{array}$ & $85.75 \pm 25.59$ & 8.32 & 166.99 \\
\hline C reactive-protein, $\mathrm{mg} / \mathrm{dl}$ & $8.07 \pm 12.79$ & 0.57 & 127.62 \\
\hline
\end{tabular}

Coronary angiography characteristics of patients

In our study group $175(86.2 \%)$ patients had right coronary dominance. The prevalence of CAD in LEAD patients was $75.4 \%$ (153/203). Among these patients, 49.8\% (101/203) had multivessel-CAD and 25.6\% (52/203) had had single-CAD. LM lesions were found in $34 \%(69 / 203)$ of patients, including $32 \%(65 / 203)$ of patients with $<50 \%$ stenosis, $0.5 \%(1 / 203)$ of patients with $50-75 \%$ stenosis and $1.5 \%$ (3/203) of patients with $>75 \%$ stenosis. $57.6 \%$ (117/203) patients had significant LAD stenosis, 39.5\% (80/203) patients had significant CxA stenosis and $44.82 \%(91 / 203)$ patients had significant RCA stenosis (table no. 3).

Table no. 3. Coronary angiography characteristics of patients

\begin{tabular}{|c|c|c|c|}
\hline $\begin{array}{l}\text { Characteristic } \\
\mathbf{N}=\mathbf{2 0 3} \text { patients }\end{array}$ & & Frequency & $\begin{array}{l}\text { Percent } \\
(\%)\end{array}$ \\
\hline Dominance & $\begin{array}{l}\text { Right } \\
\text { Left } \\
\text { Co-dominance }\end{array}$ & $\begin{array}{c}175 \\
22 \\
6\end{array}$ & $\begin{array}{c}86.2 \\
10.8 \\
3\end{array}$ \\
\hline $\begin{array}{l}\text { Significant/non- } \\
\text { significant CAD }\end{array}$ & $\begin{array}{l}\text { Non-significant CAD } \\
\text { Significant CAD }\end{array}$ & $\begin{array}{c}50 \\
153 \\
\end{array}$ & $\begin{array}{l}24.6 \\
75.4 \\
\end{array}$ \\
\hline $\begin{array}{l}\text { Non- } \\
\text { significant/single/mul } \\
\text { tivessel- CAD }\end{array}$ & $\begin{array}{l}\text { Non-significant CAD } \\
\text { Single-CAD } \\
\text { Multivessel-CAD }\end{array}$ & $\begin{array}{c}50 \\
52 \\
101 \\
\end{array}$ & $\begin{array}{l}24.6 \\
25.6 \\
49.8\end{array}$ \\
\hline Lesion severity & $0-50 \%$ & $50-75 \%$ & $75-100 \%$ \\
\hline LM & $199(98 \%)$ & $1(0.5 \%)$ & $3(1.5 \%)$ \\
\hline \multicolumn{4}{|c|}{$\begin{array}{l}\text { LM - no (no stenosis): } 134(66 \%) \\
\text { LM - yes (stenosis of any severity): } 69(34 \%)\end{array}$} \\
\hline LAD & $\begin{array}{l}86 \\
(42.4 \%)\end{array}$ & $\begin{array}{l}77 \\
(37.9 \%)\end{array}$ & $\begin{array}{l}40 \\
(19.7 \%)\end{array}$ \\
\hline $\mathrm{CxA}$ & $\begin{array}{l}123 \\
(60.6 \%)\end{array}$ & $\begin{array}{l}33 \\
(16.3 \%)\end{array}$ & $\begin{array}{l}47 \\
(23.2 \%)\end{array}$ \\
\hline RCA & $\begin{array}{l}112 \\
(55,17 \%)\end{array}$ & $21(10.34 \%)$ & $\begin{array}{l}70 \\
(34.48 \%)\end{array}$ \\
\hline
\end{tabular}

/multivessel-CAD

In our study group, significant lesions $>50 \%$ in iliac segment were not associated with multivessel-CAD ( $p$ 0.271) (table no. 5).

Instead, in patients with significant arterial stenosis $(>50 \%)$ in femoral segment, the percentage of multivessel-CAD was higher than the percentage of single-CAD and nonsignificant CAD, respectively (94\% versus $78.8 \%$ versus $86 \%$, respectively). The difference was statistically significant $\left(\chi^{2}=11.8\right.$, df $\left.4 \mathrm{p}=0.019\right)$ (table no. 5). As a measure of association, it was used the gamma- $\gamma$ coefficient, indicating a proportion of $30.2 \%$ of the association of multivessel-CAD with significant femoral lesions, but without statistical significance $(p$ $0.157)$.

Similar result was found for infrapopliteal segment: in 


\section{CLINICAL ASPECTS}

patients with significant arterial stenosis $(>50 \%)$ in infrapopliteal segment, the percentage of multivessel-CAD was higher than the percentage of single-CAD and non-significant CAD, respectively $(90.1 \%$ versus $88.5 \%$ versus $72 \%$, respectively). The difference was statistically significant $\left(\chi^{2}=9.9, \mathrm{df}=4 \mathrm{p}=0.041\right)$ (table no. 5). As a measure of association, it was used the gamma- $\gamma$ coefficient, indicating a proportion of $27.8 \%$ of the association of multivessel-CAD with significant infrapopliteal lesions, but without statistical significance ( $\mathrm{p} 0.59)$.

Table no. 5. Association of LEAD with non-significant/single -/multivessel-CAD

\begin{tabular}{|c|c|c|c|c|c|}
\hline \multirow{2}{*}{ CAD } & \multicolumn{3}{|c|}{ Iliac segment - lesion severity (\%) } & \multicolumn{2}{|c|}{ Chi-Square test } \\
\hline & $0-50$ & $50-75$ & $75-100$ & $\chi^{2}$ & $\mathrm{p}$ \\
\hline $\begin{array}{l}\text { Non- } \\
\text { significant } \\
\text { CAD }\end{array}$ & $\begin{array}{l}26 \\
(52 \%)\end{array}$ & $\begin{array}{l}4 \\
(8 \%)\end{array}$ & $20(40 \%)$ & \multirow{3}{*}{5.165} & \multirow{3}{*}{0.271} \\
\hline Single-CAD & $\begin{array}{l}22 \\
(42.3 \%)\end{array}$ & $\begin{array}{l}11 \\
(21.2 \%)\end{array}$ & $\begin{array}{l}19 \\
(36.5 \%)\end{array}$ & & \\
\hline $\begin{array}{l}\text { Multivessel- } \\
\text { CAD }\end{array}$ & $\begin{array}{l}44 \\
(43.6 \%)\end{array}$ & $\begin{array}{l}23 \\
(22.8 \%)\end{array}$ & $\begin{array}{l}34 \\
(33.7 \%)\end{array}$ & & \\
\hline \multirow[t]{2}{*}{ CAD } & \multicolumn{3}{|c|}{$\begin{array}{l}\text { Femoral segment - lesion severity } \\
(\%)\end{array}$} & \multicolumn{2}{|c|}{ Chi-Square test } \\
\hline & $0-50$ & $50-75$ & $75-100$ & $\chi^{2}$ & $\mathrm{p}$ \\
\hline $\begin{array}{l}\text { Non- } \\
\text { significant } \\
\text { CAD }\end{array}$ & $\begin{array}{l}7 \\
(14 \%)\end{array}$ & $\begin{array}{l}1 \\
(2 \%)\end{array}$ & $\begin{array}{l}42 \\
(84 \%)\end{array}$ & \multirow{3}{*}{11.803} & \multirow{3}{*}{0.019} \\
\hline Single-CAD & $\begin{array}{l}11 \\
(21.2 \%)\end{array}$ & $\begin{array}{l}1 \\
(1.9 \%)\end{array}$ & $\begin{array}{l}40 \\
(76.9 \%)\end{array}$ & & \\
\hline $\begin{array}{l}\text { Multivessel- } \\
\text { CAD }\end{array}$ & $\begin{array}{l}6 \\
(5.9 \%) \\
\end{array}$ & $\begin{array}{l}9 \\
(8.9 \%) \\
\end{array}$ & $\begin{array}{l}86 \\
(85.1 \%) \\
\end{array}$ & & \\
\hline \multirow[t]{2}{*}{ CAD } & \multicolumn{3}{|c|}{$\begin{array}{l}\text { Infrapopliteal segment - lesion } \\
\text { severity }(\%)\end{array}$} & \multicolumn{2}{|c|}{ Chi-Square test } \\
\hline & $0-50$ & $50-75$ & $75-100$ & $\chi^{2}$ & $\mathrm{p}$ \\
\hline $\begin{array}{l}\text { Non- } \\
\text { significant } \\
\text { CAD }\end{array}$ & $\begin{array}{l}14 \\
(28 \%)\end{array}$ & $\begin{array}{l}1 \\
(2 \%)\end{array}$ & $\begin{array}{l}35 \\
(70 \%)\end{array}$ & \multirow{3}{*}{9.950} & \multirow{3}{*}{0.041} \\
\hline Single-CAD & $\begin{array}{l}6 \\
(11.5 \%)\end{array}$ & $\begin{array}{l}3 \\
(5.8 \%)\end{array}$ & $\begin{array}{l}43 \\
(82.7 \%)\end{array}$ & & \\
\hline $\begin{array}{l}\text { Multivessel- } \\
\text { CAD }\end{array}$ & $10(9.9 \%)$ & $\begin{array}{l}6 \\
(5.9 \%) \\
\end{array}$ & $\begin{array}{l}85 \\
(84.2 \%) \\
\end{array}$ & & \\
\hline
\end{tabular}

$C A D$

Association of LEAD with significant/non-significant

The association of significant arterial lesions $>50 \%$ in iliac and femoral segments with significant CAD (>50\%) was not statistically significant with a $\mathrm{p}$ value of 0.134 for iliac segment and 0.394 for femoral segment.

On the other hand, in the present study, $133(89.2 \%)$ patients with significant infrapopliteal lesions $(>50 \%)$ had significant-CAD (>50\%), compared with $16(10.7 \%)$ cases with infrapopliteal lesions below $50 \%$ that had significant-CAD. The association was statistically significant $\left(\chi^{2}=8.1, \mathrm{df}=2, \mathrm{p}=0.017\right)$.

Association of LEAD with LM lesions

The association of significant arterial lesions $>50 \%$ in iliac and femoral segments with the presence of LM lesion was not statistically significant with a $\mathrm{p}$ value of 0.278 for iliac segment and 0.091 for femoral segment.

Significant infrapopliteal lesions $(>50 \%)$ were significantly associated with LM lesions (p 0.043), as shown in table no. 7.

Table no. 7. Association of significant infrapoplileal lesions (>50\%) with LM lesions

\begin{tabular}{|l|l|l|l|c|c|}
\hline \multirow{2}{*}{ LM lesion } & \multicolumn{2}{|l|}{$\begin{array}{l}\text { Infrapopliteal segment - lesion } \\
\text { severity (\%) }\end{array}$} & \multicolumn{2}{c|}{ Chi-Square test } \\
\cline { 2 - 4 } & $0-50$ & $50-75$ & $75-100$ & $\chi^{2}$ & $\mathrm{p}$ \\
\hline $\begin{array}{l}\text { No (no } \\
\text { stenosis) }\end{array}$ & $\begin{array}{l}19 \\
(14.3 \%)\end{array}$ & $\begin{array}{l}11.5 \%) \\
(84.2 \%)\end{array}$ & \\
\hline $\begin{array}{l}\text { Yes } \\
\text { (stenosis of } \\
\text { any } \\
\text { severity) }\end{array}$ & $\begin{array}{l}11 \\
(15.9 \%)\end{array}$ & $8(11.6 \%)$ & $\begin{array}{l}50 \\
(72.5 \%)\end{array}$ & 6.294 & 0.043 \\
\hline
\end{tabular}

(>50\%) is associated with LM lesion in proportion of $84.1 \%$ versus $15.9 \%$ in the case of nonsignificant lesions $\left(\chi^{2}=6.2, \mathrm{df}=2\right.$, $\mathrm{p}=0.043)$, the chance that the association is verified being 4.7 times higher ( $\mathrm{p} 0.05)$.

\section{DISCUSSIONS}

LEAD and CAD affect more frequently males than females. Age greater than 45 years for men and greater than 55 for women is associated with risk of CAD and LEAD developing.(14,15) In our study group, male gender predominance was observed and the mean age correspond to literature information.

The increased incidence of smoking, hypertension and hypercholesterolemia among studied patients coincides with literature data. $(4,5)$

Multisite artery disease is common for patients with atherosclerotic lesions ranging from 60 to $70 \%$ in patients with severe LEAD (6) - with CAD ranging from 46-71\%.(3,4,5) Significant CAD was found in more than two-thirds of patients evaluated in this study, half of patients having multivessel-CAD and one quarter having single-CAD. The interest for CAD association with LEAD is explained by the fact that the main cause of late death in patients with peripheral artery disease is ischemic heart disease (up to $50 \%$ of deaths in patients with peripheral artery disease).(16) CONFIRM registry showed that in LEAD patients, obstructive CAD was associated with annual mortality rate of $1.6 \%$ versus $0.7 \%$ in the absence of severe CAD. $(6,17)$

Proximal lesions defined as iliac, femoral, popliteal artery stenosis are more likely associated with normal or single CAD. Involvement of lower extremities proximal and distal arteries has a high chance of association with multi-vessel CAD.(5) Our study results were concordant with data mentioned above: infrapopliteal lesions were associated with both the presence and severity of CAD (defined as multi-vessel CAD and LM lesions), femoral lesions were associated with multi-vessel $\mathrm{CAD}$, while iliac lesions were not significantly associated with the presence of CAD.

Prognosis of peripheral artery disease patients is different according to lesion location.(5) Chan, et al demonstrated that the presence of lower extremity distal arterial disease is associated with a poorer prognosis compared with patients without distal disease. In contrast for patients with proximal disease there were no prognosis differences.(13) Multilevel LEAD disease determined a poorer prognosis in LEAD patients.(18) This prognosis differences may be explained by the higher association of distal and multilevel LEAD with multivessel-CAD, compared with proximal LEAD.

\section{CONCLUSIONS}

Significant CAD has a high prevalence among symptomatic LEAD patients.

Significant lesions in different segments of lower extremity arterial bed are differently associated with significant CAD.

Infrapopliteal significant lesions seems to be the strongest predictor of CAD, being associated with significant $\mathrm{CAD}$, multivessel-CAD and with the presence of LM lesions of any severity. Thus, infrapopliteal significant lesions correlates with the presence of significant CAD and also with CAD severity quantified by the number of vessels affected (multivessel-CAD) and by LM involvement.

Significant lesions in femoral segments were highly associated with multivessel CAD, but there was no association with significant $\mathrm{CAD}$ and with $\mathrm{LM}$ lesions.

Finally, there was no significant association between iliac segment lesions and significant, multivessel-CAD and LM

AMT, vol. 26, no. 1, 2021, p. 23 


\section{CLINICAL ASPECTS}

lesions.

The study results suggest that CAD evaluation should be performed in symptomatic LEAD patients, with increased attention for patients with significant lesions in femoral and infrapopliteal segments. In addition, reduced daily activity in symptomatic LEAD patients can reduce angina symptoms in CAD patients; therefore, screening for "asymptomatic" CAD might be an option for LEAD patients.

\section{REFERENCES}

1. Expert Panel on Detection, Evaluation, and Treatment of High Blood Cholesterol in Adults. Executive Summary of The Third Report of The National Cholesterol Education Program (NCEP) Expert Panel on Detection, Evaluation, And Treatment of High Blood Cholesterol In Adults (Adult Treatment Panel III). JAMA. 2001;285:2486-97.

2. Gornik HL, Creager MA. Contemporary management of peripheral arterial disease: I. Cardiovascular risk-factor modification. Cleve Clin J Med. 2006;73 Suppl 4:S30-7.

3. Sukhija R, Aronow WS, Yalamanchili K et al. Prevalence of coronary artery disease, lower extremity peripheral arterial disease, and cerebrovascular disease in 110 men with an abdominal aortic aneurysm. Am J Cardiol. 2004;94:1358-9.

4. Dieter RS, Tomasson J, Gudjonsson $\mathrm{T}$, et al. Lower extremity peripheral arterial disease in hospitalized patients with coronary artery disease. Vasc Med. 2003;8:233-6.

5. Sung Woo Cho, Byung Gyu Kim, Deok Hee Kim. Prediction of Coronary Artery Disease in Patients with Lower Extremity Peripheral Artery Disease. Int Heart J. March 2015;56:209-212.

6. Aboyans V, Ricco JB, E. L. Bartelink ML, et al. 2017 ESC Guidelines on the Diagnosis and Treatment of Peripheral Arterial Diseases, in collaboration with the European Society for Vascular Surgery (ESVS). European Heart Journal. 2018;39:763-821.

7. Hiatt WR, Fowkes FG, Heizer G, et al. Ticagrelor versus clopidogrel in symptomatic peripheral artery disease. $\mathrm{N}$ Engl J Med. 2017;376:32-40.

8. Gallino A, Aboyans V, Diehm C, et al. Non-coronary atherosclerosis. Eur Heart J. 2014;35:1112-1119.

9. Bhatt DL, Eagle KA, Ohman EM. et al. Comparative determinants of 4-year cardiovascular event rates in stable outpatients at risk of or with atherothrombosis. JAMA. 2010;304(12):1350-7.doi: 10.1001/jama.2010.1322.[PubMed: 20805624].

10. Hertzer NR, Beven EG, Young JR, et al. Coronary artery disease in peripheral vascular patients. A classification of 1000 coronary angiograms and results of surgical management. Ann Surg. 1984;199:223-33.

11. Fleisher LA, Eagle KA, Shaffer T, Anderson GF. Perioperativeand long-term mortality rates after major vascular surgery: the relationship to preoperative testing in the medicare population. Anesth Analg. 1999;89:849-55.

12. Welten GM, Schouten O, Hoeks SE, et al. Long-term prognosis of patients with peripheral arterial disease: a comparison in patients with coronary artery disease. J Am Coll Cardiol. 2008;51:1588-96.

13. Chen Q, Smith CY, Bailey KR, Wennberg PW, Kullo IJ. Disease location is associated with survival in patients with peripheral arterial disease. $\mathrm{J}$ Am Heart Assoc. 2013;2:e000304.

14. Boudi FB, Yasmine S. Risk Factors for Coronary Artery Disease: https://emedicine.medscape.com/article/164163overview\#a3 Mar 30; 2020.

15. Fowker FG, RudanD, Rudan I, et al. Comparison of global estimates of prevalence and risk factors for peripheral artery disease in 2000 and 2010: a systemic review and analysis. Lancet. 2013;382:1329-1340.

16. Norgren L, Hiatt W, Dormandy J, Nehler M, Harris K, Fowkes F.Inter-Society Consensus for the Management of Peripheral Arterial Disease (TASC II). Eur J Vasc Endovasc Surg. 2007;33:S1-S75.

17. Cho I, Chang H, Sung JM, et al. CONFIRM Investigators. Coronary computed tomographic angiography and risk of all cause mortality and nonfatal myocardial infarction in subjects without chest pain syndrome from the CONFIRM Registry (coronary CT angiography evaluation for clinical outcomes: an international multicenter registry). Circulation. 2012;126:304-313.

18. Vogt MT, Wolfson SK, Kuller LH. Segmental arterial disease in the lower extremities: correlates of disease and relationship to mortality. J Clin Epidemiol. 1993;46:126776. 